\title{
Development of Crown and Root Rot Disease of Tomato Under Irrigation with Saline Water
}

\author{
Shachaf Triky-Dotan, Uri Yermiyahu, Jaacov Katan, and Abraham Gamliel
}

First and fourth authors: Laboratory for Pest Management Research, Institute of Agricultural Engineering, ARO, The Volcani Center, P.O. Box 6, Bet Dagan 50250, Israel; second author: Soil and Water Research Unit, Gilat Research Center, ARO, D.N. Negev 85280, Israel; and third author: Department of Plant Pathology and Microbiology, The Hebrew University of Jerusalem, Faculty of Agricultural, Food and Environmental Quality Sciences, Rehovot 76100, Israel.

Accepted for publication 15 August 2005.

\begin{abstract}
Triky-Dotan, S., Yermiyahu, U., Katan, J., and Gamliel, A. 2005. Development of crown and root rot disease of tomato under irrigation with saline water. Phytopathology 95:1438-1444.

We studied the effect of water salinity on the incidence and severity of crown and root rot disease of tomato, as well as on the pathogen and on the plant's response to the pathogen. Irrigation with saline water significantly increased disease severity in tomato transplants inoculated with Fusarium oxysporum f. sp. radicis-lycopersici, and mineral fertilization further increased it. In one field experiment, disease incidence in plots irrigated with saline water (electrical conductivity $[\mathrm{EC}]=3.2 \pm$ $\left.0.1 \mathrm{dS} \mathrm{m}^{-1}\right)$ and in those irrigated with fresh water $\left(\mathrm{EC}=0.4 \pm 0.1 \mathrm{dS} \mathrm{m}^{-1}\right)$

lower in plots irrigated with saline water. In a second field experiment, final disease incidence 250 days after planting, was $12 \%$ in plants which had been irrigated with saline water $\left(\mathrm{EC}=4.6 \pm 0.1 \mathrm{dS} \mathrm{m}^{-1}\right)$ and $4 \%$ in those irrigated with fresh water $\left(\mathrm{EC}=1.2 \pm 0.1 \mathrm{dS} \mathrm{m}^{-1}\right)$. Irrigation of tomato transplants with $20 \mathrm{mM} \mathrm{NaCl}$ did not inhibit plant development, but partial inhibition was observed at higher $\mathrm{NaCl}$ concentrations. Growth of the pathogen in culture or survival of conidia added to soil were not affected by saline water. Plants which were preirrigated with saline water were more severely diseased than those preirrigated with tap water. It was concluded that disease increases effected by saline water are associated with the latter's effect on plant response.
\end{abstract} was 75 and $38 \%$, respectively. Disease onset was earlier and yield was

Crown and root rot disease of tomato, caused by Fusarium oxysporum Schlechtend.:Fr. f. sp. radicis-lycopersici W. R. Jarvis \& Shoemaker, can result in total crop destruction. Since 1982, this disease has become widespread in Israel in both greenhouses and the open field $(18,19)$. Disease symptoms include root and basal stem rot, discoloration of the vascular system in the basal stems, and wilting of the plant before fruit ripening. A pink layer of macroconidia usually appears on the stems of diseased plants $(16,32)$. Infection of the plant by the pathogen is via chlamydospores which survive in the soil, root-to-root contact, or airborne propagules (32).

Agricultural crops frequently are irrigated with saline water at various salinity levels in arid and semiarid areas, where the availability of fresh water (nonsaline, usually the electrical conductivity [EC] at $1 \mathrm{dS} \mathrm{m}^{-1}$ or less) is limited. In some areas such as the Arava valley (which is an important agricultural area), saline water from local wells is the only source of water for irrigating crops. Irrigation with saline water may have adverse effects on the physical and chemical properties of the soil, on crop production, and on plant metabolism which may, in turn, affect disease severity and plant resistance $(5,15,20,27)$. Salinity generally affects plant growth through either excess ions or water deficit, with different plant organs responding differently. Plant responses to salinity depend upon various factors, such as the duration and degree of the stress and growth stage at stress exposure. However, most agronomical crops (vegetable and fruit) do not develop well

Corresponding author: A. Gamliel; E-mail address: agamliel@agri.huji.ac.il

DOI: 10.1094/PHYTO-95-1438

This article is in the public domain and not copyrightable. It may be freely reprinted with customary crediting of the source. The American Phytopathological Society, 2005.
Additional keywords: soilborne pathogens, stress. at a salinity level equivalent to $5 \mathrm{dS} \mathrm{m}^{-1}$ or higher (23). Regarding tolerance to saline water with high EC, tomato (Lycopersicon esculentum Mill.) is considered to be moderately sensitive to salinity but adversely affected by irrigation with saline water at levels exceeding $2.5 \mathrm{dS} \mathrm{m}^{-1}$. Plant development usually is reduced with increasing salt concentrations but sugar accumulation in the fruit increases $(6,23)$.

Various pathogens are highly tolerant to salts in culture, including Aspergillus, Penicillium, and Fusarium spp. (37), Pythium aphanidermatum (30), Phytophthora spp. $(2,21)$, and F. oxysporum f. sp. vasinfectum (28).

High salinity may increase the incidence and severity of diseases caused by various species of Phytophthora $(3,21,22,33,36)$, F. oxysporum f. sp. vasinfectum (38), F. oxysporum f. sp. radicislycopersici $(17,39)$, and Verticillium dahliae and Alternaria solani (25). On the other hand, suppression of diseases under saline irrigation has been reported with Fusarium wilt of date palm (4), Rhizoctonia crown and root rot of table beet (9), Fusarium crown and root rot of asparagus $(11,12)$, and Fusarium wilt of cyclamen (10). The effect of salinity on plant disease may result from its effect on one or more of the biotic components involved in the disease: the pathogen, the host, microbial activity in the soil, or abiotic components of the soil. Soil disinfestation is done frequently in this region, which is cropped under saline water irrigation. Chemical fumigation alone or combined with other methods is effective in controlling the disease (35). However, the build up of the pathogen in soil is very fast, leading to the need for repeated fumigation prior to each crop. In the new era of phase out of fumigants, it is important to better understand the behavior and etiology of the pathogen in order to manage the disease with the limited measures which still are available.

The objectives of the present work were to (i) study the effect of water salinity on the incidence and severity of crown and root 
rot disease of tomato under controlled and field conditions and (ii) study the effect of water salinity on the pathogen in culture and in the soil, and on the plant response to the pathogen.

\section{MATERIALS AND METHODS}

Soils. Three types of soil, referred to as soils 1, 2, and 3, were used. Soil 1 was an agricultural sandy soil from the central part of Israel, at Rehovot. Soil characteristics obtained by routine procedures were: contents of clay, silt, and sand, 4, 2, and 94\%, respectively; organic matter, $1.0 \mathrm{~g} \mathrm{~kg}^{-1} ; \mathrm{pH}$ determined in $1: 1$ water extract (wt/wt), 7.9; water-holding capacity, 9\% wt/wt. Soil 2 was collected from the southern desert, Arava region, at Ein Tamar. Soil characteristics obtained by routine procedures were: contents of clay, silt, and sand, 4, 7, and $89 \%$, respectively; organic matter, $1.4 \mathrm{~g} \mathrm{~kg}^{-1} ; \mathrm{pH}$ determined in 1:1 water extract (wt/wt), 8.1; waterholding capacity, $8 \% \mathrm{wt} / \mathrm{wt}$. Soil 3 was collected from the Ashalim Experimental Station at Ramat Negev, in the central Israeli desert. Soil characteristics obtained by routine procedures were: contents of clay, silt, and sand, 4, 3, and 93\%, respectively; organic matter, $2.7 \mathrm{~g} \mathrm{~kg}^{-1} ; \mathrm{pH}$ determined in $1: 1$ water extract (wt/wt), 7.6; waterholding capacity, $8 \% \mathrm{wt} / \mathrm{wt}$. Soils 2 and 3 both were from fields with diseased tomato plants infected with $F$. oxysporum f. sp. radicis-lycopersici. For laboratory studies, the infested soils were collected from the root zone of diseased plants at the end of the crop season and air dried.

Fusarium population counts by soil dilution. Soil samples $(2.5 \mathrm{~g})$ were added to $22.5 \mathrm{ml}$ of sterile water agar $(0.1 \% \mathrm{wt} / \mathrm{vol})$ containing $\mathrm{MgSO}_{4} \cdot 7 \mathrm{H}_{2} \mathrm{O}(0.1 \% \mathrm{wt} / \mathrm{vol})$. The samples were shaken for $45 \mathrm{~min}$ in a reciprocal shaker $(200 \mathrm{rpm})$. Aliquots of $0.2 \mathrm{ml}$ were spread on four petri dishes which contained peptone-pentachloronitrobenzene selective agar medium (FSM) (14). Plates were incubated in the dark at $28^{\circ} \mathrm{C}$ for 4 to 6 days. Randomly selected colonies of $F$. oxysporum isolates originating from soil or stems of diseased plants were tested for pathogenicity using tomato transplants, in order to verify their identity as $F$. oxysporum f. sp. radicis-lycopersici (13). Results are expressed as CFU per gram of dry soil $\left(105^{\circ} \mathrm{C}\right.$ for $\left.48 \mathrm{~h}\right)$.

Fusarium oxysporum f. sp. radicis-lycopersici inocula. First, soil 2, naturally infested with the pathogen, was stored for over 9 months at room temperature $\left(25^{\circ} \mathrm{C}\right)$. Before each test, a population of the pathogen was assayed as already described. Second, the basal parts of stems from diseased tomato plants (cv. 5656), which were covered with a typical pink-orange layer of conidia of F. oxysporum f. sp. radicis-lycopersici ( $60 \%$ macroconidia), were collected from the field at the end of the crop season and stored in paper bags at room temperature $\left(25^{\circ} \mathrm{C}\right)$. Water suspensions of the conidia at predetermined concentrations were used. Their viability was determined by incubating on FSM for $17 \mathrm{~h}$ at $17^{\circ} \mathrm{C}$ and assessing germination. Conidia were considered viable when the length of the germ tube was twice that of the conidium. We used conidial stocks with $>90 \%$ germination.

Effect of saline water irrigation and fertilizers in greenhouse tests on crown and root rot disease. Two weeks after emergence (with two true leaves), tomato transplants (cv. 870 contributed by Shorashim nurseries, Ein Habesor, Israel) were exposed for 2 weeks to irrigation with tap or saline water $(20 \mathrm{mM}$ $\mathrm{NaCl}$ ). Then, tomato transplants were inoculated with $F$. oxysporum f. sp. radicis-lycopersici by first rinsing the root with water, to remove adhering growth medium, then dipping for $5 \mathrm{~min}$ in conidial suspension of $F$. oxysporum $\mathrm{f}$. sp. radicis-lycopersici obtained from tomato stems $\left(1 \times 10^{6} \mathrm{ml}^{-1}\right.$ in tap or saline water). After inoculation, the tomato transplants were replanted in noninfested Rehovot soil and were irrigated with either tap or saline water, as specified. Three plants were planted in each pot $(12-\mathrm{cm}$ diameter, 15-cm depth) and were fertilized with liquid fertilizer Shefer 1 (Deshanim Ltd., Israel) containing 7\% N $\left(60 \% \mathrm{~N}^{-\mathrm{NO}_{3}}\right)$, $3 \% \mathrm{P}_{2} \mathrm{O}_{5}, 7 \% \mathrm{~K}_{2} \mathrm{O}$, and the necessary amounts of iron, man- ganese, zinc, cooper, and molybdenum, at $0.1 \%$ in the irrigation solutions, for 28 days in the greenhouse at $20^{\circ} \mathrm{C}$. After those 28 days, the plants were uprooted and assayed for vascular discoloration after longitudinally sectioning the stem and rated on a scale of 0 to 4 , where $0=$ healthy plants without discoloration or wilt, and 1 to $4=$ slight discoloration symptoms to dead plants. Both the average disease index of all plants and the percentage of severely diseased plants (ranked 2 to 4 ) were calculated.

In an additional experiment, the effect of fertilizers also was examined. Tomato transplants were irrigated with tap water and fertilized with Shefer 1 ( $0.1 \%$ in the irrigation solutions) before inoculation. After inoculation, plants were transplanted to noninfested soil and irrigated with tap or saline water with or without the addition of fertilizers at $0.1 \%$ in the irrigation solutions.

Effect of irrigation with saline water on crown and root rot disease under field conditions. The first field experiment was conducted at the Zohar Experimental Station at Ein Tamar (soil 2 ), in the southeastern desert in Israel, in soil with a long history of crown and root rot disease. At the end of the previous crop, the incidence of crown rot on tomato plants was $>80 \%$. Tomato transplants (cv. 5656, highly susceptible to the disease) were planted in the open field on 25 September 2001. Each plot was $11 \mathrm{~m}$ long and contained one row of plants, $0.5 \mathrm{~m}$ between plants. Half of the plots were irrigated with fresh water $\left(\mathrm{EC}=0.4 \pm 0.1 \mathrm{dS} \mathrm{m}^{-1}\right)$ and half were irrigated with local saline water $\left(E C=3.2 \pm 0.1 \mathrm{dS} \mathrm{m}^{-1}\right)$ to the end of experiment, in February 2002, both via dripping system. The experiment consisted of five replicates per treatment in a randomized complete block design. The plots were prepared, cultivated, and treated according to the recommendations of the extension service in that region. Disease symptoms appeared 75 days after planting. The diseased plants with crown rot symptoms, which collapsed, were recorded periodically.

Soil samples from the root zone were taken at certain intervals after planting in order to assess Fusarium populations in the root system zone, as described earlier. Samples of soil and irrigation water were taken for chemical analysis, 120 days after planting. Chemical properties of soil irrigated with fresh water as tested in saturated paste were $\mathrm{EC}=0.45 \mathrm{dS} \mathrm{m} \mathrm{m}^{-1}, \mathrm{Na}=0.60 \mathrm{mM}, \mathrm{Ca}=$ $1.13 \mathrm{mM}$, and $\mathrm{Mg}=0.27 \mathrm{mM}$. The properties of soil irrigated with saline water were $\mathrm{EC}=1.61 \mathrm{dS} \mathrm{m}{ }^{-1}, \mathrm{Na}=4.30 \mathrm{mM}, \mathrm{Ca}=$ $3.92 \mathrm{mM}$, and $\mathrm{Mg}=1.75 \mathrm{mM}$. Chemical properties of fresh irrigation water were $\mathrm{EC}=0.44 \mathrm{dS} \mathrm{m}^{-1}, \mathrm{Na}=1.95 \mathrm{mM}$, and $\mathrm{Ca}=$ $5.01 \mathrm{mM}, \mathrm{pH}=6.76$ and for saline irrigation water were $\mathrm{EC}=$ $3.24 \mathrm{dS} \mathrm{m}^{-1}, \mathrm{Na}=14.24 \mathrm{mM}$, and $\mathrm{Ca}=4.78 \mathrm{mM}, \mathrm{pH}=7.59$.

The second experiment was conducted in a greenhouse at the Ashalim Experimental Station in Ramat Negev (soil 3), in the central Israeli desert, in a soil with a long history of irrigation with saline water. The incidence of crown root disease in tomato plant at the end of the previous season was 40 to $50 \%$. Tomato transplants (cv. 144, moderately susceptible to the disease) were planted on 4 September 2002. Each plot was $8 \mathrm{~m}$ long and contained eight rows of plants, with $0.5 \mathrm{~m}$ between plants. All plots were irrigated with fresh water $\left(\mathrm{EC}=1.2 \pm 0.1 \mathrm{dS} \mathrm{m} \mathrm{m}^{-1}\right)$ by dripping system until the end of October 2002. After that, half of the plots were irrigated with local saline water $(\mathrm{EC}=4.6 \pm$ $\left.0.1 \mathrm{dS} \mathrm{m}^{-1}\right)$ and the other half with fresh water $(\mathrm{EC}=1.2 \pm$ $0.1 \mathrm{dS} \mathrm{m}^{-1}$ ) until the end of the experiment in May 2003. The experiment consisted of four replicates per treatment in a randomized complete block design. The plots were prepared, cultivated, and treated according to the recommendations of the extension service in that region. Disease symptoms appeared 80 days after planting, and plants showing typical disease symptoms were recorded periodically and removed from the greenhouse to prevent possible aerial infection from sporulating diseased plants with spores on the stems (31). At the end of the experiment, in May 2003, all remaining plants were uprooted and evaluated for late symptoms of crown and root rot disease, which were not visible until that time. 
Samples of soil and irrigation water were taken for chemical analysis, 120 days after planting. Chemical properties of soil irrigated with fresh water as tested in saturated paste were $\mathrm{EC}=$ $0.72 \mathrm{dS} \mathrm{m}^{-1}, \mathrm{Na}=4.00 \mathrm{mM}, \mathrm{Ca}=0.62 \mathrm{mM}$, and $\mathrm{Mg}=0.31 \mathrm{mM}$. The properties of soil irrigated with saline water were $\mathrm{EC}=$ $1.52 \mathrm{dS} \mathrm{m}^{-1}, \mathrm{Na}=10.00 \mathrm{mM}, \mathrm{Ca}=0.98 \mathrm{mM}$, and $\mathrm{Mg}=0.46 \mathrm{mM}$. Chemical properties of fresh irrigation water were $\mathrm{EC}=$ $1.20 \mathrm{dS} \mathrm{m} \mathrm{m}^{-1}, \mathrm{Na}=5.85 \mathrm{mM}$, and $\mathrm{Ca}=1.59 \mathrm{mM}, \mathrm{pH}=7.22$ and for saline irrigation water were $\mathrm{EC}=4.60 \mathrm{dS} \mathrm{m} \mathrm{m}^{-1}, \mathrm{Na}=$ $27.93 \mathrm{mM}$, and $\mathrm{Ca}=5.15 \mathrm{mM}, \mathrm{pH}=7.15$.

Chemical analysis of leaf contents was carried out 120 days after planting. Leaves of five plants (the fifth leaf from the top) were removed from each plot, dried at $65^{\circ} \mathrm{C}$, and digested with $\mathrm{H}_{2} \mathrm{SO}_{4}$ and $\mathrm{H}_{2} \mathrm{O}_{2} ; \mathrm{N}$ and $\mathrm{P}$ contents were determined by a colorimetric method with Lachat autoanalyzer and $\mathrm{K}$ content was determined by flame spectrometry.

Growth of tomato plants under saline water irrigation in the greenhouse. Tomato transplants (cv. 870, contributed by Shorashim nurseries) were planted in drained pots $(15 \mathrm{~cm}$ in diameter) which contained a mixture of sandy Rehovot soil with perlite (15\% vol/wt, no. 4; Agrikal, Habonim, Israel) to improve soil drainage. Plants were irrigated every 3 days to drainage with saline water at different rates of $\mathrm{NaCl}$, as described. The control plants were irrigated with tap water. The EC of the drained water from each pot was assessed following every irrigation by conductivity meter (B-173, Horbita, Kyoto, Japan). The salts were found not to accumulate in the soil. The plants were fertilized once a week with Shefer 1 ( $0.1 \%$ in irrigation solutions) and were kept at controlled temperature $\left(25^{\circ} \mathrm{C}\right)$ in the greenhouse. After 4 weeks, chlorophyll level was assessed by chlorophyll meter (SPAD 502, Minolta, Osaka, Japan). Then, plants and roots were removed to assess root volume (by the change of water height in a narrow water tube) and fresh and dry weight in grams (48 $\mathrm{h}$ of drying at $\left.80^{\circ} \mathrm{C}\right)$.

Pathogen growth and development on salt-amended medium. Petri dishes containing Czapek agar (7) amended with 0 to $600 \mathrm{mM}$ $\mathrm{NaCl}$ or $\mathrm{KCl}$ (five plates for each salt concentration) were inoculated with culture disks (8-mm diameter) of $F$. oxysporum f. sp. radicis-lycopersici. The plates were incubated in the dark at $28^{\circ} \mathrm{C}$. The colony area was assessed at 24-h intervals and plotted against incubation time.

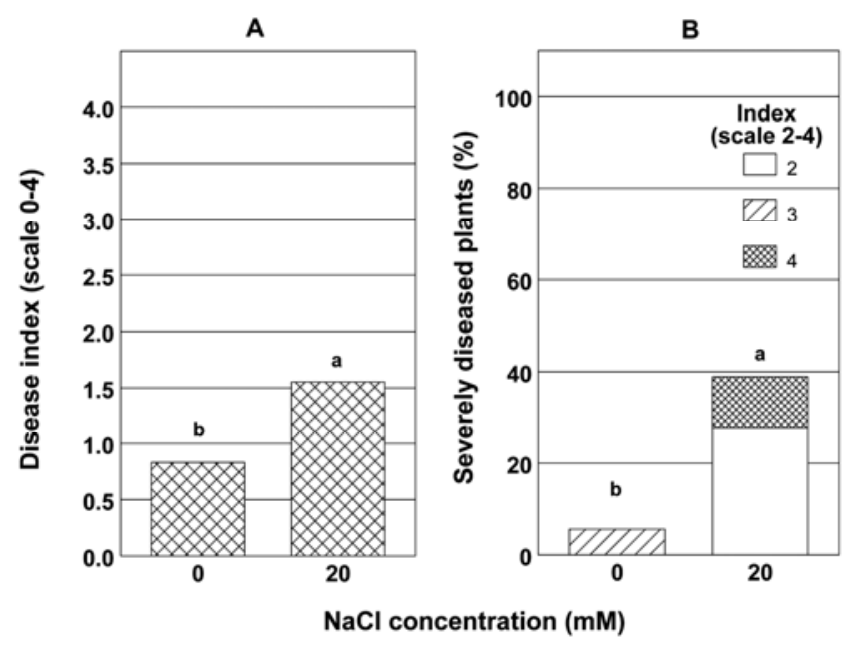

Fig. 1. Effect of irrigation with saline water after inoculation on $\mathbf{A}$, crown and root rot disease severity and $\mathbf{B}$, incidence of severely diseased tomato plants in a greenhouse experiment. Roots were dipped in a conidial suspension of Fusarium oxysporum f. sp. radicis-lycopersici and plants were transplanted to noninfested soil and irrigated with tap water $(0 \mathrm{mM} \mathrm{NaCl})$ or with saline water $(20 \mathrm{mM} \mathrm{NaCl})$. Disease assessment was based on a 0-to-4 severity scale, where $0=$ no vascular discoloration or wilt and $4=$ plant death. Different letters within $\mathbf{A}$ or $\mathbf{B}$ denote significant differences among treatments $(P \leq 0.05)$.
Pathogen survival in soil under saline water irrigation. Conidial suspensions of $F$. oxysporum $\mathrm{f}$. sp. radicis-lycopersici taken from diseased tomato stems were suspended in distilled water and agitated for $1 \mathrm{~min}$ at the highest speed (Vortex-Genie, Springfield, MA). The conidial suspension was mixed with soil 2 to a final concentration of $1 \times 10^{5}$ conidia/g. The infested soil was put into 1-liter drained pots $(15 \mathrm{~cm}$ depth) which then were irrigated to drainage with saline water of $0,2,4$, and $10 \mathrm{dS} \mathrm{m}^{-1} \mathrm{NaCl}$ every 3 days $\left(1.17 \mathrm{~g}\right.$ of $\mathrm{NaCl} \operatorname{liter}^{-1}$ of $\mathrm{H}_{2} \mathrm{O}, \approx 20 \mathrm{mM} \mathrm{NaCl}$, $\approx 2 \mathrm{dS} \mathrm{m}^{-1}$ ). The pots were kept for 28 days at $25^{\circ} \mathrm{C}$. Soil samples were assayed every 7 days for population density of $F$. oxysporum f. sp. radicis-lycopersici by the soil dilution method. The indigenous population of $F$. oxysporum f. sp. radicis-lycopersici in this soil consisted of $\approx 1 \%$ of the conidia added to the soil, which alone cannot produce disease symptoms within 30 days of incubation.

Effect of saline water irrigation on plant predisposition to disease. Tomato transplants were grown in noninfested soil irrigated with either tap or saline $(20 \mathrm{mM} \mathrm{NaCl})$ water. After 14 days, the plants were removed and their roots were washed and inoculated with conidia of $F$. oxysporum f. sp. radicis-lycopersici obtained from stems of diseased plants. Half of the plants, from each of the two treatments, then were transplanted in noninfested soil and irrigated with tap water only to assess the effect on predisposition to disease. The other half of the plants were transplanted in noninfested soil and irrigated with saline water to assess the effect of irrigation with saline water, after inoculation, on disease. Plants from all treatment were fertilized every 3 days with Shefer $1(0.1 \%$ in the irrigation solutions).

Statistical analyses. All laboratory and greenhouse experiments were conducted at least twice. Data which were taken as percentages were arcsin transformed before analysis. Nonparametric variables such as disease index were analyzed using the rank procedure followed by analysis of variance. The effects of disease and water salinity were tested by two-way analysis of variance. The combinations were compared by one-way analysis of variance and interaction effects were tested by contrast $t$ tests. All treatment means were compared simultaneously by the Fisher protected test for significant differences. All analyses were performed with the SAS program (SAS Institute, Cary, NC, and release 8.01 for PC) at $P \leq 0.05$.

\section{RESULTS}

Effect of saline water irrigation and fertilizers in greenhouse tests on crown and root rot disease. Tomato transplants were inoculated with conidia of $F$. oxysporum f. sp. radicislycopersici collected from stems of naturally infected plants. Subsequent irrigation with saline water significantly increased disease severity in the inoculated tomato transplants (Fig. 1). Similarly, the percentages of severely diseased plants were 5 and $39 \%$ for plants irrigated with tap or saline water, respectively, after inoculation (Fig. 1B).

Mineral fertilization of inoculated tomato transplants further increased disease severity under irrigation with saline water (Fig. 2). For example, the percentages of diseased plants ranked 3 and 4 for disease severity in the nonfertilized plants were 0,11 , and $16 \%$ for 0,20 , and $50 \mathrm{mM} \mathrm{NaCl}$, respectively, whereas the respective numbers for the fertilized plants were 0,39 , and $44 \%$. Dead plants (grade 4) were observed only in pots which were both irrigated with saline water and fertilized (Fig. 2B). Significant differences were obtained $(P \leq 0.001)$ for the main effects (i.e., irrigation and mineral fertilization), but no interaction between effects was recorded.

The shoots of plants that had been irrigated without fertilizer were chlorotic compared with those of plants which had been fertilized. However, the roots of the nonfertilized plants were larger in volume, root diameter, and branching (data not shown). 
Effect of irrigation with saline water on crown and root rot disease under field conditions. The first field experiment was carried out at the Zohar Experimental Station in Ein Tamar, in a field which had been irrigated with saline water $(\mathrm{EC}=3.2 \pm$ $0.1 \mathrm{dS} \mathrm{m}^{-1}$ ) for 10 years. The tomato cultivar in this open field crop was 5656, which is highly susceptible to crown and root rot disease. First symptoms of crown and root rot disease appeared 75 days after planting (Fig. 3). High disease incidence (75\%) was evident in plots which were irrigated with saline water, compared with $38 \%$ in plots which were irrigated with fresh water $(\mathrm{EC}=$ $0.4 \pm 0.1 \mathrm{dS} \mathrm{m}^{-1}$ ). Similarly, area under disease progress curve values were significantly higher in plots irrigated with saline water, and disease onset was earlier and yield was lower in plots irrigated with saline water, compared with irrigation with fresh water.

Leaf analysis was carried out 120 days after planting, to assess the effects of water salinity on mineral availability and transport in plants. The mineral content in plants irrigated with fresh water was (in percentage of dry matter) was $\mathrm{Na}=0.20, \mathrm{~N}=3.40, \mathrm{P}=$ 0.49 , and $\mathrm{K}=3.10$, and in those irrigated with saline water was $\mathrm{Na}=0.32, \mathrm{~N}=2.90, \mathrm{P}=0.39$, and $\mathrm{K}=2.00$.

Soil samples were taken from the root zone of the plants at certain intervals after planting. The buildup of Fusarium populations in soil was faster and to a higher level under saline water irrigation (Fig. 4). At 90 days after planting, the population reached 1,500 CFU/g of soil compared with 396 in the plots which were irrigated with fresh water. The fast buildup of $\mathrm{Fu}$ sarium spp. corresponds with the earlier disease onset in the plants which were irrigated with saline water (Fig. 3).

In the second experiment at the Ashalim Experimental Station in Ramat Negev, the first symptoms of crown and root rot disease appeared 80 days after planting. Essentially, the results confirmed those of the first field experiment. Thus, final disease incidence, 250 days after planting, was $12 \%$ in plants which had been irrigated with saline water compared with $4 \%$ in plants irrigated with fresh water (Fig. 5). At the end of the experiment, the remaining plants were uprooted and examined for late disease symptoms of crown and root rot (i.e., symptoms which could not be detected earlier in the season). A high incidence of late disease symptoms $(50 \%)$ was evident in plots irrigated with saline water, compared

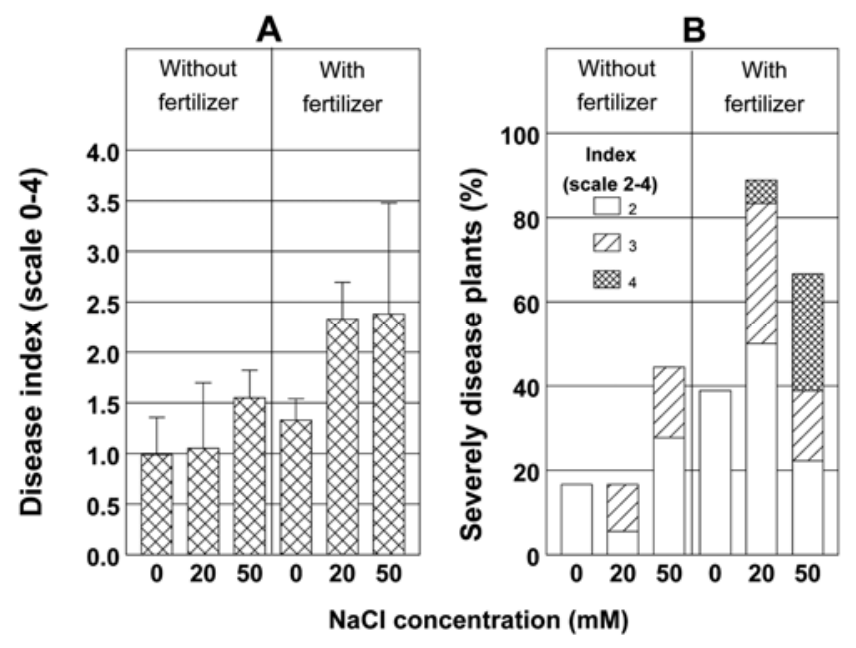

Fig. 2. Effect of mineral fertilization and water salinity on $\mathbf{A}$, crown and root rot disease severity and $\mathbf{B}$, incidence of severely diseased tomato plants inoculated with Fusarium oxysporum f. sp. radicis-lycopersici. After inoculation, plants were planted in noninfested soil and irrigated with $0 \mathrm{mM} \mathrm{NaCl}$ (tap water) or saline water at 20 or $50 \mathrm{mM} \mathrm{NaCl}$, with or without fertilizer. Disease assessment was based on a 0 -to- 4 severity scale, where $0=$ no vascular discoloration or wilt $4=$ plant death. Vertical bars are standard deviation for each column. Statistical analysis of the main effects show a significant effect of water salinity $(P \leq 0.0055)$ and mineral fertilization $(P \leq 0.0003)$ on disease severity, but no interaction was evident $(P \leq 0.0666)$ with $16 \%$ in plots irrigated with fresh water. Irrigation with saline water caused a significant reduction in yield (by 15\%). Analysis of chemical leaf contents for $\mathrm{N}, \mathrm{P}$, and $\mathrm{K}$ were similar to these obtained in Ein Tamar experiment (data not shown).

Growth of tomato plants under saline water irrigation in the greenhouse. Irrigation of tomato transplants with saline water (20 mM NaCl, which is considered as a moderate salinity level) did not inhibit plant development (Fig. 6). At higher salt concentrations, root volume and shoot fresh weight were reduced by 24 and $66 \%$, respectively, at $100 \mathrm{mM} \mathrm{NaCl}$, relative to tap water. At $200 \mathrm{mM} \mathrm{NaCl}$, root volume was reduced by $38 \%$ and shoot fresh weight by $99 \%$, relative to tap water. Irrigation with saline water increased chlorophyll counts by $18 \%$ at $70 \mathrm{mM} \mathrm{NaCl}$; however, at $200 \mathrm{mM} \mathrm{NaCl}$, counts were lower by $10 \%$ compared with tap water.

Pathogen growth and development on salt-amended medium. Growth of $F$. oxysporum f. sp. radicis-lycopersici in culture was not adversely affected when the concentration of $\mathrm{NaCl}$ or $\mathrm{KCl}$ was at or below $100 \mathrm{mM}$ (Fig. 7). Only when the salt concen-
A

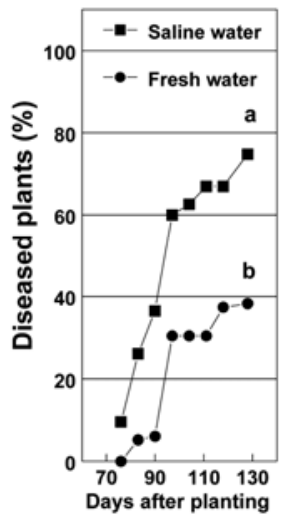

B

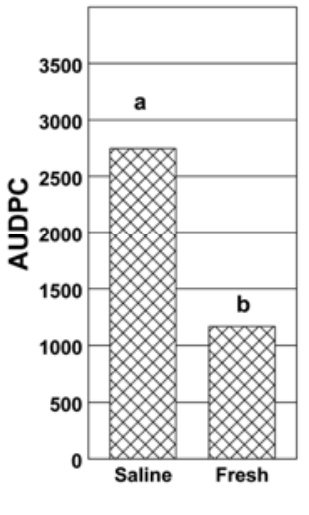

C

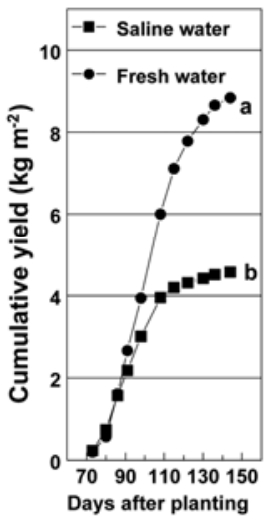

Fig. 3. Effect of water salinity on A, incidence of crown and root rot disease, $\mathbf{B}$, area under disease progress curve (AUDPC), and $\mathbf{C}$, tomato cumulative yield $\left(\mathrm{kg} \mathrm{m}^{-2}\right)$ at the Zohar Experimental Station in Ein Tamar. The plants were irrigated with either fresh water (electrical conductivity $[\mathrm{EC}]=0.4 \pm$ $0.1 \mathrm{dS} \mathrm{m}^{-1}$ ) or saline water $\left(E C=3.2 \pm 0.1 \mathrm{dS} \mathrm{m}^{-1}\right)$. Different letters within A, $\mathbf{B}$, and $\mathbf{C}$ denote significant differences among treatments $(P \leq 0.05)$.

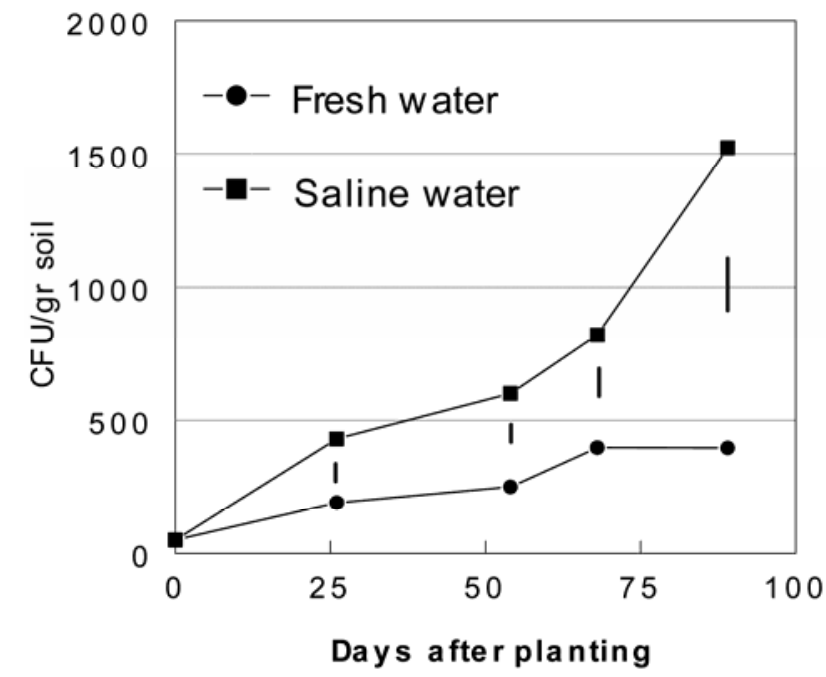

Fig. 4. Effect of water salinity on buildup of Fusarium population at the root zone in soil during tomato crop at the Zohar Experimental Station in Ein Tamar. The plants were irrigated with either fresh water (electrical conductivity $\left.[\mathrm{EC}]=0.4 \pm 0.1 \mathrm{dS} \mathrm{m}^{-1}\right)$ or saline water $\left(\mathrm{EC}=3.2 \pm 0.1 \mathrm{dS} \mathrm{m}^{-1}\right)$. Vertical lines indicate standard deviation. 
trations exceeded $200 \mathrm{mM}$ was colony area significantly reduced. Germination of conidia from infected stems was not affected (95\% viability) when they were incubated in a $20 \mathrm{mM} \mathrm{NaCl}$ salt solution for 10 min (data not shown).

Pathogen survival in soil with saline water irrigation. Survival in soil of conidia of $F$. oxysporum f. sp. radicis-lycopersici originating from naturally infected stems under saline water irrigation to drainage (up to $100 \mathrm{mM} \mathrm{NaCl}$ ) was similar to that in soil irrigated with tap water (Fig. 8). Their population was reduced with all treatments to $\approx 20 \%$ of their initial numbers after 21 days.

In a similar experiment, a soil 2 sample, which naturally contains chlamydospores (13), was irrigated with either tap or saline water (up to $80 \mathrm{mM} \mathrm{NaCl}$ ). The population of $F$. oxysporum f. sp. radicis-lycopersici after 60 days of incubation was reduced from 3,500 to $\approx 3,000 \mathrm{CFU} / \mathrm{g}$ of soil with all treatments, without significant differences (data not shown). Thus, survival of chlamydo-
A

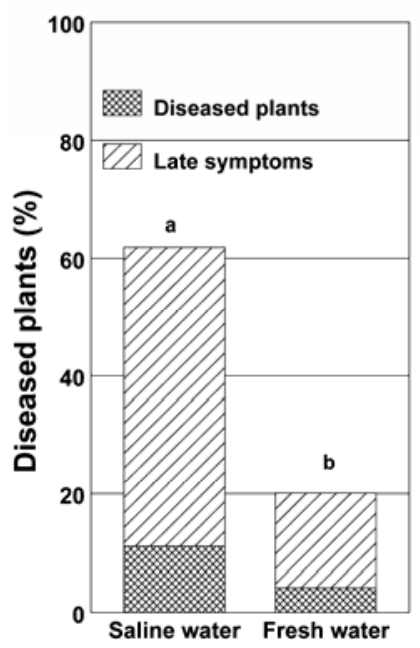

B

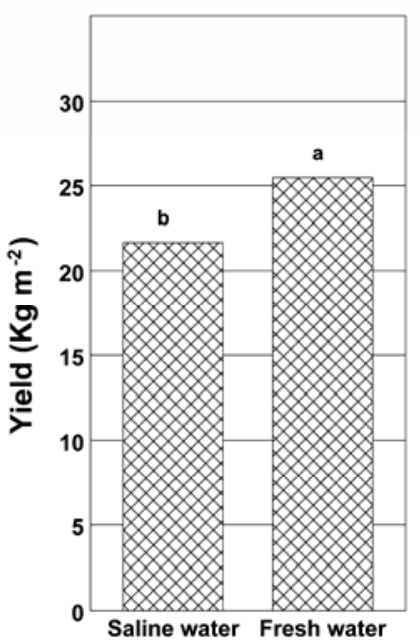

Fig. 5. Effect of water salinity on $\mathbf{A}$, incidence of crown and root rot disease and $\mathbf{B}$, tomato yield $\left(\mathrm{kg} \mathrm{m}^{-2}\right)$ at the Ashalim Experimental Station in Ramat Negev. The plants were irrigated with either fresh water (electrical conductivity $\left.[E C]=1.2 \pm 0.1 \mathrm{dS} \mathrm{m}^{-1}\right)$ or saline water $\left(E C=4.6 \pm 0.1 \mathrm{dS} \mathrm{m}^{-1}\right)$. Plants showing typical disease symptoms were recorded and uprooted until 250 days after planting. All remaining plants then were uprooted and assayed for late symptoms of disease. Different letters within A and B denote significant differences among treatments $(P \leq 0.05)$.
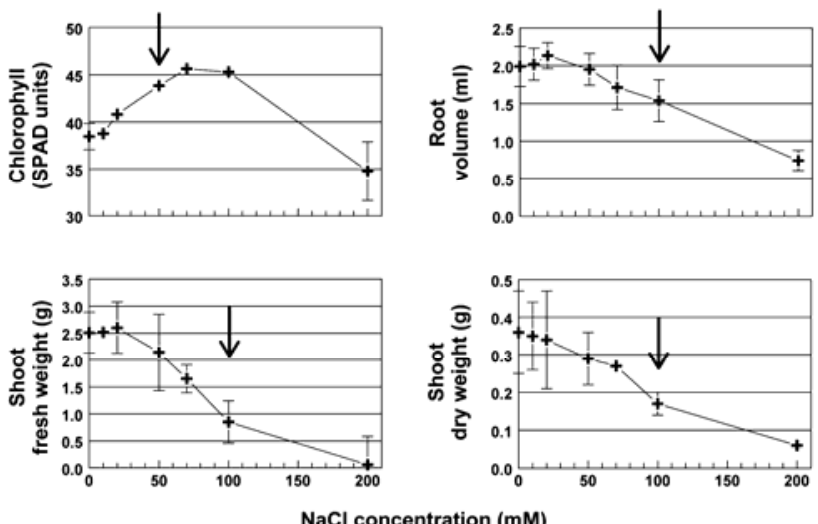

Fig. 6. Effect of water salinity on development parameters of tomato plants. Plants were irrigated with tap water $(0 \mathrm{mM} \mathrm{NaCl})$ or saline water $(10$ to $200 \mathrm{mM}$ $\mathrm{NaCl}$ ) for 28 days. Shoot fresh weight represents weight additional to that of the plants on the day of planting. Vertical bars are standard deviation for each value. Arrows indicate the $\mathrm{NaCl}$ concentration at which the tested parameter is significantly different from tap water (except for the last measurement by SPAD) according to $t$ test $(P=0.05)$. spores under natural conditions, namely, when exposed to microbial activity, was not significantly affected by irrigation with saline water at the tested levels, similar to survival of conidia from stem in the soil, the other type of natural inoculum.

Effect of saline water irrigation on plant predisposition to disease. To assess the effect of a previous irrigation with saline water on predisposition to disease, noninoculated tomato plants were irrigated with either tap or saline water and afterward removed, their roots washed and inoculated, and transplanted to a new soil where all plants were irrigated with tap water. Plants which were preirrigated with saline water were more severely diseased than those preirrigated with tap water (77 versus $38 \%$ ) (Fig. 9A). Additional irrigation with saline water after inoculation increased disease severity in plants which had been preirrigated with fresh water but it barely increased disease in plants which previously had been irrigated with saline water (Fig. 9B).

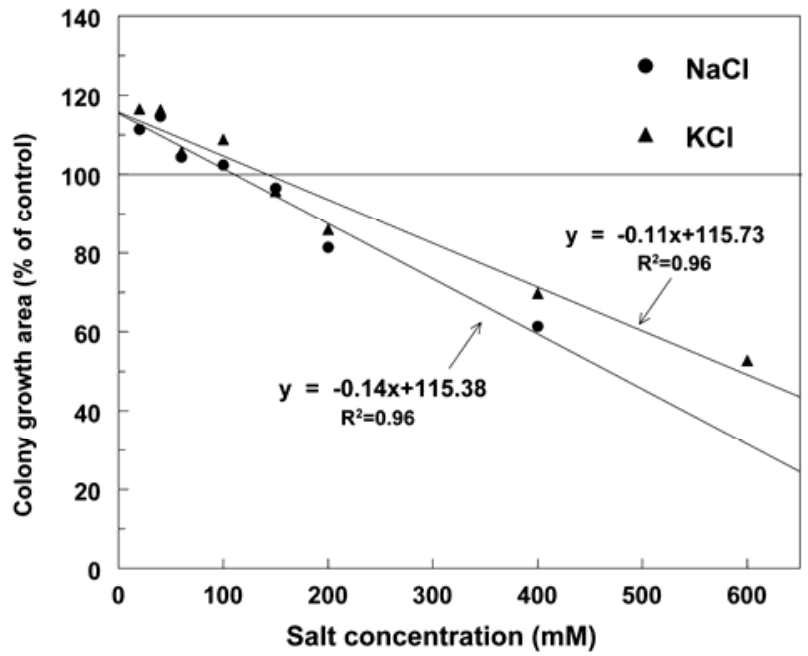

Fig. 7. Effect of $\mathrm{KCl}$ and $\mathrm{NaCl}$ concentration (mM) added to Czapek agar medium on relative growth of Fusarium oxysporum f. sp. radicis-lycopersici after $96 \mathrm{~h}$ of incubation in the dark at $28^{\circ} \mathrm{C}$. Regression line expresses colony development versus salt concentration. Growth in the nonamended control was considered to be $100 \%$ (horizontal line).

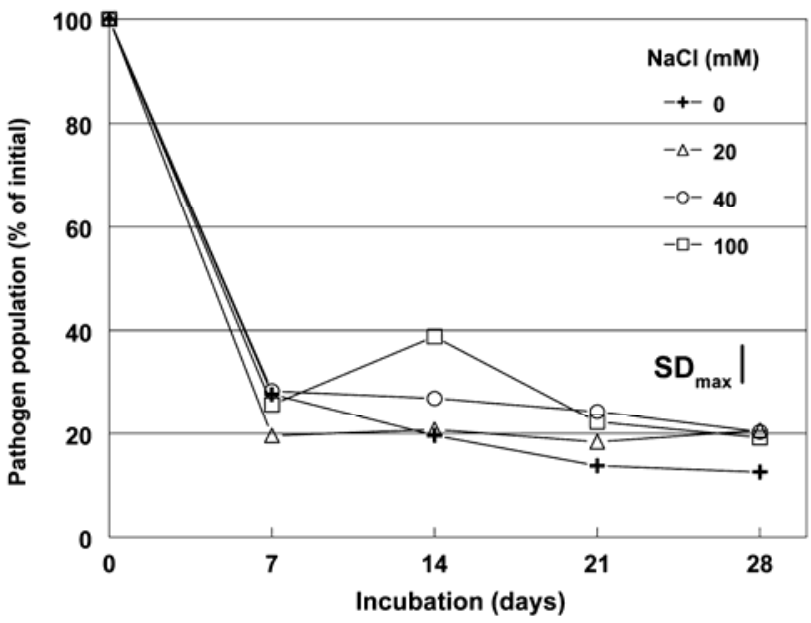

Fig. 8. Decline in conidial population of Fusarium oxysporum f. sp. radicislycopersici (naturally produced on tomato stems) added to soil and irrigated with saline water ( 0 to $100 \mathrm{mM} \mathrm{NaCl}$ ). Initial population of conidia was $\approx 10^{4}$ per gram of soil. Results are expressed as percentage of initial during 28 days of incubation at $25^{\circ} \mathrm{C}$. Standard deviation $\left(\mathrm{SD}_{\max }\right)$ at the final data point was $8 \%$ of initial. No significant differences were found between treatments $(P \geq 0.05)$ 


\section{DISCUSSION}

The incidence and severity of crown and root rot disease of tomato were significantly increased under irrigation with saline water, as observed under both controlled and field conditions. Moreover, the pathogen buildup at the root zone in soil was faster, the disease onset came earlier, and yield was significantly reduced under saline water irrigation. The increase in disease incidence and severity following irrigation with saline water was validated in field experiments with high inoculum density. The field plots had been irrigated continuously with saline water for the previous 10 years. The long-term irrigation with saline water, as well as frequent cropping of tomato, appears to be responsible for the increase in disease incidence in these fields. Increased disease incidence following irrigation with high-salinity water had been reported with a variety of soilborne pathogens, including pathogenic forms of Fusarium $(3,17,21,22,25,35,37-39)$. It will be interesting to study, in the future, the effect of salinity on diseases in salt-tolerant cultivars.

Mineral fertilization of plants irrigated with saline water further increased the severity of crown and root rot disease (Fig. 2). Woltz et al. (39) and Jones et al. (17) found that mineral fertilization with $\left(\mathrm{NH}_{4}\right)_{2} \mathrm{SO}_{4}$, irrigation with saline water $(\mathrm{NaCl})$, and an acidic environment $(\mathrm{pH}<4)$ enhanced disease severity of tomato. Low concentrations of $\mathrm{NO}_{3}^{-}$fertilization (39 to $79 \mathrm{mg} \mathrm{liter}^{-1}$ ) reduced disease severity of crown and root rot in hydrophonically grown tomato; however, high concentrations of fertilizer, $>100 \mathrm{mg}$ liter $^{-1}$, increased disease severity (8). In our system, a level of $\mathrm{NO}_{3}^{-}$at $85 \mathrm{mg} \mathrm{liter}^{-1}$, using commercial fertilizer, was sufficient to increase disease incidence and severity. The availability and absorption of minerals by plants differ in saline environments compared with nonsaline conditions (6). Irrigation of tomato plants in noninfested soil with saline water $(20 \mathrm{mM} \mathrm{NaCl})$ did not affect plant development; however, at higher concentrations ( $>100 \mathrm{mM} \mathrm{NaCl}$ ), plant growth was adversely affected (Fig. 6).

The increase in disease incidence and severity following irrigation with saline water can be attributed to an effect on one or more of the biotic components involved in disease: pathogen, microbial antagonistic activity, and host resistance or susceptibility. Moreover, salinity may affect physical-chemical properties of the soil (e.g., aggregation and aeration) and these in turn may affect the aforementioned biotic components. Various studies have shown that high salinity can affect one or more of these biotic components. In the present study, neither growth in culture of F. oxysporum f. sp. radicis-lycopersici (Fig. 7) nor conidial germination were affected by water salinity at $100 \mathrm{mM} \mathrm{NaCl}$, indicating that this pathogen tolerates a high salinity level, even levels at which crop growth is damaged. Thus, there is no evidence that high salinity stimulates this pathogen, although the effect on virulence (29) was not tested. Tolerance of soil fungi to high salinity levels has been demonstrated in other studies $(2,21$, 28,30 ). In this study, the survival in soil of two types of natural inoculum, chlamydospores and conidia, produced on stems (Fig. 8) was not affected by high salinity. Survival in natural soil is connected directly with microbial activity. Thus, a possible effect of saline water via increased plant susceptibility to the pathogen, the third biotic component, should be considered.

We demonstrated an effect on the plant's predisposition to disease. A short exposure of 14 days to high salinity (in the absence of pathogen) was sufficient to render the plants significantly more susceptible to subsequent inoculation with the pathogen (Fig. 9A). A subsequent irrigation with fresh water did not alleviate the increased susceptibility, indicating that the salinity stress is a "plastic strain" (i.e., it is irreversible) (34). Additional exposure to high salinity after inoculation, thereby exposing both the pathogen and the soil organisms to high salinity, did not further increase disease severity (Fig. 9B); this result emphasized the importance of the effect of salinity on plant susceptibility or resis- tance. Increased susceptibility of plants exposed to disease by high salinity has been reported with various pathogens. Salinity stress increased Phytophthora root rot in chrysanthemum $(21,22)$. The increased root rot was attributed directly to the effect of salinity on the host without any concomitant salinity effect on the pathogen. The salinity stress was regarded as a predisposing factor. Salinity increased Phytophthora root rot in tomato, even though it reduced zoospore release and motility (36). Salinity increased the incidence of Phytophthora root rot of citrus (3), Pythium blight in Agrostis spp. (30), and Phytophthora capsici in chile pepper (33), and those increases were attributed to an effect on plant susceptibility.

High salinity may affect plant physiology via morphological, anatomical, metabolic, and biochemical changes, such as water relations; number and size of stomata; stem, leaf, root, and membrane structure; photosynthesis; protein synthesis; lipid metabolism; thickening of the cuticle; ion homeostasis and membrane function; water uptake and transport, salt accumulation; metabolic pathways; and synthesis of osmolytes, enzymes, and nucleic acids $(1,5,15,20,26,27)$. The above changes inflicted on the plant by high salinity might be associated with increased susceptibility to the pathogen. Salinity may lead to decrease in other nutrient ions in the tissues $(1,26)$, including $\mathrm{K}^{+}$, which frequently is connected with resistance to pathogens. Salinity imposes on the plant osmotic stress, lowered water potential, and water deficit $(1,24)$, which may further enhance wilt severity. Another factor to consider is the effect of salinity on root exudates (1), which are a crucial factor in the early stages of infection by a soilborne pathogen.

Increased disease incidence with increased salinity is not a general rule. On the contrary, some diseases are suppressed by high salinity, including Fusarium wilt of date palm under irrigation with water having an $\mathrm{EC}=20 \mathrm{dS} \mathrm{m}^{-1}$ (4), Rhizoctonia root and crown rot of table beets (9), and Fusarium crown and root rot of asparagus, apparently due to increasing Mn levels in the root cells, which induces disease resistance (12). Application of $\mathrm{NaCl}$ did not affect the final disease incidence (but delayed onset of disease symptoms) in cyclamen infected with $F$. oxysporum f. sp. cyclaminis (10).

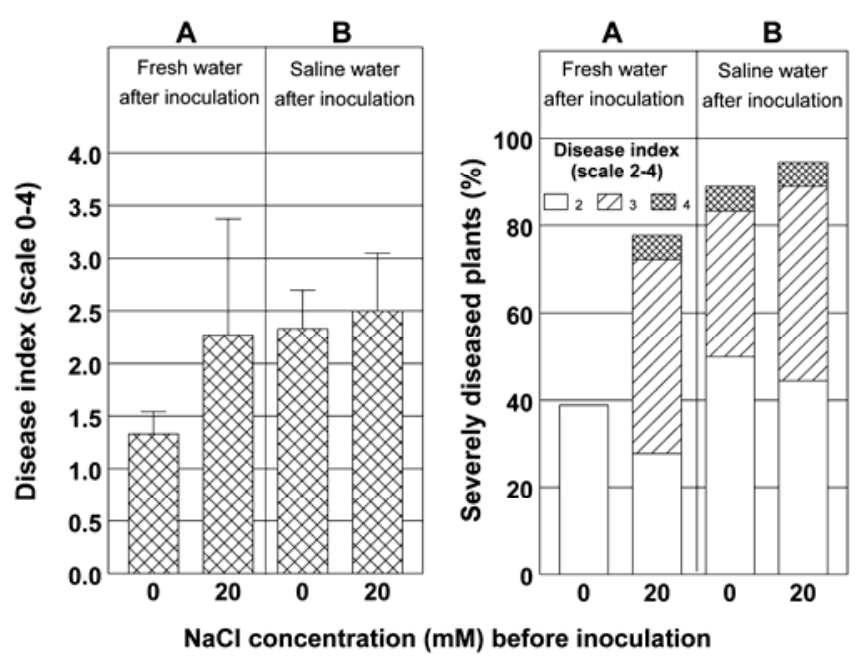

Fig. 9. Effect of irrigation with saline or tap water before or after inoculation with Fusarium oxysporum f. sp. radicis-lycopersici of tomato plants on crown and root rot disease severity and incidence of severely diseased plants. Before inoculation, plants were irrigated with tap water $(0 \mathrm{mM} \mathrm{NaCl})$ or saline water $(20 \mathrm{mM} \mathrm{NaCl})$. After inoculation, plants were planted in noninfested soil and irrigated with $\mathbf{A}$, tap water $(0 \mathrm{mM} \mathrm{NaCl})$ or $\mathbf{B}$, saline water $(20 \mathrm{mM} \mathrm{NaCl})$. Disease assessment was based on a 0 -to- 4 severity scale, where $0=$ no vascular discoloration or wilt and $4=$ plant death. Vertical bars are standard deviation for each column. Statistical analysis of the main effects shows a significant effect of water salinity before $(P \leq 0.0153)$ and after $(P \leq 0.0284)$ inoculation on disease severity, but no interaction was evident $(P \leq 0.0842)$. 
Our findings concerning the interaction of crown and root rot disease of tomato with salinity correspond with studies in other pathosystems and indicate that the use of high-salinity water for irrigation is harmful from a phytopathological perspective extending beyond its direct damage to the plant. Thus, high salinity may adversely affect plant health in a very broad sense, an aspect which needs to be more thoroughly considered.

\section{ACKNOWLEDGMENTS}

We thank the staff of the Zohar Experimental Station in the Arava region and of the Ashalim Experimental Station at Ramat Negev for their valuable assistance in the field experiments; V. Zilberg, M. Beniches, M. Siti, M. Austerweil, B. Steiner, J. Rivan, and E. Klein for their technical assistance; Y. Rekah, Y. Kapulnik, U. Kafkafi, Z. Plaut, E. Zamski, and A. Schwartz for helpful suggestions and useful comments; and Shorashim Nurseries for contribution of transplants.

\section{LITERATURE CITED}

1. Bernstein, N., and Kafkafi, U. 2002. Root growth under salinity stress. Pages 787-805 in: Plant Root, the Hidden Half. 3rd ed. Y. Waisel, A. Eshel, and U. Kafkafi, eds. Marcel Dekker, New York.

2. Blaker, N. S., and MacDonald, J. D. 1985. Effect of soil salinity on the forming of sporangia and zoospores by three isolates of Phytophthora. Phytopathology 75:270-274.

3. Blaker, N. S., and MacDonald, J. D. 1986. The role of salinity in the development of Phytophthora root rot of citrus. Phytopathology 76:970975.

4. Brac de la Perriere, R. A., Amir, H., and Bounaga, N. 1995. Prospects for integrated control of "bayoud" (Fusarium wilt of the date palm) in Algerian plantations. Crop Prot. 14:227-235.

5. Campbell, L. C., and Pitman, M. G. 1971. Salinity and plant cells. Pages 207-224 in: Salinity and Water Use. T. Talsma and J. R. Philip, eds. MacMillan Press, London.

6. Cuartero, J., and Fernandez-Munoz, R. 1999. Tomato and salinity. Sci. Hortic. 78:83-125.

7. Dhingra, O. D., and Sinclair, J. B. 1995. Basic Plant Pathology Methods. 2nd ed. CRC Press, Boca Raton, FL.

8. Duffy, B. K., and Defago, G. 1999. Macro- and microelement fertilizers influence the severity of Fusarium crown root rot of tomato in a soilless production system. HortScience 34:287-291.

9. Elmer, W. H. 1997. Influence of chloride and nitrogen form on Rhizoctonia root and crown rot of table beets. Plant Dis. 81:635-640.

10. Elmer, W. H. 2002. Influence of inoculum density of Fusarium oxysporum f. sp. cyclaminis and sodium chloride on cyclamen and the development of Fusarium wilt. Plant Dis. 86:389-393.

11. Elmer, W. H. 2003. Local and systemic effects of $\mathrm{NaCl}$ on root composition, rhizobacteria, and Fusarium crown and root rot of asparagus. Phytopathology 93:186-192.

12. Elmer, W. H., and LaMondia, J. A. 1999. Studies on the suppression of Fusarium crown and root rot of asparagus with $\mathrm{NaCl}$. Acta Hortic. 479:211-217.

13. Eshel, D., Gamliel, A., Grinstein, A., and Katan, J. 1999. Evaluation of soil fumigants on soilborne fungal pathogens in a controlled-environment system and in soil. Crop Prot. 18:437-443.

14. Gamliel, A., and Katan, J. 1991. Involvement of fluorescent pseudomonads and other microorganisms in increased growth response of plants in solarized soils. Phytopathology 81:494-502.

15. Hasegawa, P. M., Bressan, R. A., Zhu, J. K., and Bohnert, H. J. 2000. Plant cellular and molecular responses to high salinity. Annu. Rev. Plant Physiol. Plant Mol. Biol. 51:463-499.
16. Jarvis, W. R. 1988. Fusarium crown and root rot of tomatoes. Phytoprotection 69:49-64.

17. Jones, J. P., Jones, J. B., Woltz, S. S., and Scott, J. W. 1993. Influence of soil $\mathrm{pH}$, nitrogen source, and transplant drenches on development of crown rot of tomato. Proc. Fla. State Hortic. Soc. 106:170-172.

18. Katan, T., Zamir, D., Sarfatti, M., and Katan, J. 1991. Vegetative compatibility groups and subgroups in Fusarium oxysporum f. sp. radicislycopersici. Phytopathology 81:255-262.

19. Krikun, J., Nachmias, A., Cohn, R., and Lahkim-Tsror, L. 1982. The occurrence of Fusarium crown and root rot of tomato in Israel. Phytoparasitica 10:113-115.

20. Kylin, A., and Quatrano, R. S. 1975. Metabolic and biochemical aspects of salt tolerance. Pages 147-167 in: Plants in Saline Environments. A. Poljakoff-Mayber and J. Gale, eds. Springer-Verlag, Berlin.

21. MacDonald, J. D. 1982. Effect of salinity stress on the development of Phytophthora root rot of Chrysanthemum. Phytopathology 72:214-219.

22. MacDonald, J. D. 1984. Salinity effects on the susceptibility of Chrysanthemum roots to Phytophthora cryptogea. Phytopathology 74:621-624.

23. Mass, E. V. 1986. Salt tolerance of plants. Appl. Agric. Res. 1:12-26.

24. Munns, R. 2002. Comparative physiology of salt and water stress. Plant Cell Environ. 25:239-250.

25. Nachmias, A., Kaufman, Z., Livescu, L., Tsror, L., Meiri, A., and Caligari, P. D. S. 1993. Effects of salinity and its interactions with disease incidence on potato grown in hot climates. Phytoparasitica 21:245-255.

26. Parida, A. K., and Das, A. B. 2005. Salt tolerance and salinity effects on plants: A review. Ecotoxicol. Environ. Safety 60:324-349.

27. Poljakoff-Mayber, A. 1975. Morphological and anatomical changes in plants as a response to salinity stress. Pages 97-117 in: Plants in Saline Environments. A. Poljakoff-Mayber and J. Gale, eds. Springer-Verlag, Berlin.

28. Ragazzi, A., and Vecchio, V. 1992. Behaviour of chlamydospore of Fusarium oxysporum f. sp. vasinfectum in substrates containing sodium chloride. Phytopathol. Mediterr. 31:85-87.

29. Ragazzi, A., Vecchio, V., Dellavalle, I., Cucchi, A., and Mancini, F. 1994. Variations in the pathogenicity of Fusarium oxysporum f. sp. vasinfectum in relation to the salinity of the nutrient medium. J. Plant Dis. Prot. 101:263-266.

30. Rasmussen, S. L., and Stanghellini, M. E. 1988. Effect of salinity stress on development of Pythium blight in Agrostis palustris. Phytopathology 78:1495-1497

31. Rekah, Y., Shtienberg, D., and Katan, J. 1999. Spatial distribution and temporal development of Fusarium crown and root rot of tomato and pathogen dissemination in field soil. Phytopathology 89:831-839.

32. Rekah, Y., Shtienberg, D., and Katan, J. 2001. Population dynamics of Fusarium oxysporum f. sp. radicis-lycopersici in relation to the onset of Fusarium crown and root rot of tomato. Eur. J. Plant Pathol. 107:367-375.

33. Sanogo, S. 2004. Response of chile pepper to Phytophthora capsici in relation to soil salinity. Plant Dis. 88:205-209.

34. Schoeneweiss, D. F. 1975. Predisposition, stress and plant disease. Annu. Rev. Phytopathol. 13:193-211.

35. Sivan, A., Chet, I., and Ucko, O. 1993. Integrated control of Fusarium crown and root rot of tomato with Trichoderma harzianum in combination with methyl bromide or soil solarization. Crop Prot. 12:380-386.

36. Swiecki, T. J., and MacDonald, J. D. 1991. Soil salinity enhances Phytophthora root rot of tomato but hinders asexual reproduction by Phytophthora parasitica. J. Am. Soc. Hortic. Sci. 116:471-477.

37. Tresner, H. D., and Hayes, J. A. 1971. Sodium chloride tolerance of terrestrial fungi. Appl. Microbiol. 22:210-213.

38. Turco, E., Naldini, D., and Ragazzi, A. 2002. Disease incidence and vessel anatomy in cotton plants infected with Fusarium oxysporum f. sp. vasinfectum under salinity stress. Z. Pflanzenkrankh. Pflanzenschutz 109:15-24

39. Woltz, S. S., Jones, J. P., and Scott, J. W. 1992. Sodium chloride, nitrogen source, and lime influence Fusarium crown rot severity in tomato. HortScience 27:1087-1088. 